\title{
HEALTHCARE WASTE TREATMENT TECHNOLOGIES AND HEALTH IMPACTS OF WASTE MANAGEMENT*
}

\author{
NESLI AYDIN \\ Faculty of Engineering, Department of Environmental Engineering, University of Karabuk, \\ Karabuk, Turkey
}

\begin{abstract}
Healthcare waste includes all types of waste generated from human and veterinary medical activities (public or private), and encompasses diagnosis, prevention and curative treatments, research, and laboratory activities. The risks associated with healthcare waste and its management have gained attention across the world over last decades, and this has resulted in the increased recognition of the need for proper healthcare waste management. One of the most important factors in any type of waste management is undoubtedly safety and hence the basic safety for waste treatment workers on the site has to be guaranteed first. However, some waste treatment technologies, such as landfills and incinerators, release toxic substances which could cause significant health effects. There are two purposes of this paper: (1) to review the technologies available for the treatment of healthcare wastes (HCW) by indicating the major merits and drawbacks of them, and (2) to highlight adverse health implications of these technologies reported in the epidemiology to provide data and information regarding excess health risk of these technologies for further studies. If there are not a significant number of health effect investigations specifically related to HCW treatment and disposal, municipal waste will be used as a surrogate for healthcare waste.

Keywords: health effect, healthcare waste, incinerator, landfills, safety, toxic substances.
\end{abstract}

\section{INTRODUCTION}

Adoption of proper healthcare waste service became a priority for regulatory authorities since the destructive impacts of improper management of healthcare waste were figured out by the environmental agencies. However, it has recently been understood that treating wastes at incinerators or at landfills could have a high potential to cause health problems as these treatment methods release toxic substances [1,2]. For example, studies on workers at incinerators and populations residing near to these plants have identified a wide range of associated health impacts. These studies give rise to great concerns regarding possible health impacts from incinerators, even though the number of studies is highly limited. For this reason, more sophisticated health surveillance of waste disposal and treatment facilities is still needed for a better understanding of these methods' health implications.

This paper presents some of the most common treatment methods utilized in the management of HCW. The methods discussed include: high- temperature technology (incineration), non-burn low-temperature technologies (autoclave, hydroclave and microwave) and landfill. Background information on the technologies is included to provide information to those who may not be familiar with the details of each alternative. This research aims to review:

\footnotetext{
*This research is related to the $\mathrm{PhD}$ project, which was undertaken in the School of Civil Engineering, the University of Leeds and sponsored by the Republic of Turkey Ministry of National Education. The author extends her thanks to Tubitak (The Scientific and Technological Research Councilof Turkey) for travel support (project code: 114Y048).
} 
1. Recent technologies available for the treatment of HCW with their advantages and disadvantages by investigating a number of technology producers across Europe, the US and Canada or currently commercialised companies across the world.

2. Adverse health implications of these technologies reported in the epidemiology to provide data and information regarding excess health risk for further studies.

\section{AVAILABLE TECHNOLOGIES FOR HEALTHCARE WASTES}

Available technologies for HCW will be examined under two groups: (1) High-temperature (incineration) technology and (2) Non-burn/low-temperature alternative technologies. Since landfilling of HCW without pre-treatment is forbidden by the EU Landfill Directive [3], it is not involved as an option by itself, but reviewed in this section as it is one of the most common methods applied in developing countries.

Table 1 provides the HCW treatment and disposal methods across the world based on the analysis of available literature.

\subsection{Landfilling}

In developing countries, landfills are generally operated like an open dump [4]. In practice, $\mathrm{HCW}$ is dumped in the pits mixed with municipal wastes, and later burned [5]. Yong et al. [6] reported that in Nanjing Province, China, since a disposal cost mechanism had not been developed based on the market economics, higher disposal costs often encouraged some hospitals to dispose of their HCW by themselves.

\subsection{High-temperature (incineration) technology}

Incineration is a high-temperature dry oxidation process that converts the waste into residual ash and gases. It consists of a primary combustion chamber operating at $800-1000^{\circ} \mathrm{C}$ and a secondary chamber operating at $850-1100^{\circ} \mathrm{C}$.

There are often two shortcomings regarding the use of incinerators in developing countries reported in the literature. Firstly, these incinerators are poorly designed and run inappropriately. Nemathaga [5] investigated an incinerator of Tshilidzini hospital in Limpopo Province and found out that the incinerator was generating high amounts of ash because of incomplete burning of the waste. Secondly, they require high investment, operation and maintenance costs along with costly emission control equipment [20].

\subsection{Non-burn/Low-temperature alternative technologies}

Currently available alternative technologies for the treatment of HCW require suitable land disposal facilities [19]. The main principle of these technologies is to render the waste "safe". "Rendering safe" is defined by the Safe Management of Healthcare Waste Document published by the Department of Health in the UK DoH [21] to be applied to:

(1) Infectious waste: It demonstrates the ability to reduce the number of infectious organisms present in the waste to a level that no additional precautions are needed to protect workers or the public against infection by the waste; (2) Anatomical waste: It destroys anatomical waste such that it is no longer generally recognisable; (3) All clinical waste (including any equipment and sharps): They render all clinical waste unusable and unrecognisable; (4) 
Table 1: Various countries and their common healthcare waste treatment methods.

\begin{tabular}{|c|c|c|}
\hline Country & Method & Reference \\
\hline Bangladesh (Dhaka City) & $\begin{array}{l}\text { Dumping } \\
\text { Autoclave }\end{array}$ & Hassan et al. [7] \\
\hline $\begin{array}{l}\text { Brazil (State of Rio } \\
\text { Grande do Sul) }\end{array}$ & $\begin{array}{l}\text { Incineration } \\
\text { Autoclave }\end{array}$ & Da Silva et al. [8] \\
\hline Denmark & $\begin{array}{l}\text { Incineration } \\
\text { Other Alternative Technologies }\end{array}$ & Bagge [9] \\
\hline Germany & $\begin{array}{l}\text { Incineration } \\
\text { Autoclave }\end{array}$ & Hempen [10] \\
\hline $\begin{array}{l}\text { Greece (Central } \\
\text { Macedonia) }\end{array}$ & $\begin{array}{l}\text { Incineration } \\
\text { Autoclave }\end{array}$ & Karagiannidis et al. [11] \\
\hline India & $\begin{array}{l}\text { Open burning } \\
\text { Open dumping }\end{array}$ & Patil and Shekdar [12] \\
\hline Iran (Fars Province) & $\begin{array}{l}\text { Open dumping } \\
\text { Incineration }\end{array}$ & Askarian et al. [13] \\
\hline Libya & $\begin{array}{l}\text { Open dumping } \\
\text { Incineration }\end{array}$ & Sawalem et al. [14] \\
\hline Nigeria (Ibadan) & $\begin{array}{l}\text { Open dumping } \\
\text { Incineration }\end{array}$ & Coker et al. [15] \\
\hline Palestinian Territory & $\begin{array}{l}\text { Open burning } \\
\text { Thermal disinfection } \\
\text { Incineration }\end{array}$ & Al-Khatib and Sato [16] \\
\hline $\begin{array}{l}\text { South Africa (Limpopo } \\
\text { Province) }\end{array}$ & $\begin{array}{l}\text { Incineration } \\
\text { Autoclave } \\
\text { Open dumping } \\
\text { Landfill }\end{array}$ & Nemathaga et al. [5] \\
\hline Sweden & $\begin{array}{l}\text { Incineration } \\
\text { Autoclave }\end{array}$ & Christiansson [17] \\
\hline Turkey & $\begin{array}{l}\text { Landfilling } \\
\text { Incineration } \\
\text { Autoclave }\end{array}$ & Ciplak [18] \\
\hline UK & $\begin{array}{l}\text { Incineration } \\
\text { Alternative Technologies }\end{array}$ & Tudor et al. [19] \\
\hline
\end{tabular}

Medicinal waste: It destroys the component chemicals of chemical or medicinal and medicinally contaminated waste.

Following the same document, for infectious waste, the treatment must demonstrate, as a minimum, Level III criteria. For cultures of pathogenic microorganisms (pre-maceration or shredding is not appropriate for such wastes) it should show at least Level IV criteria provided by the US State and Territorial Association on Alternative Treatment Technologies (STAAT) guidelines [22]. 


\subsection{Autoclaves}

The autoclave consists of a metal cylindrical vessel which is surrounded by a steam jacket. Waste containers are loaded into a vessel on a cycle/batch base and are exposed to elevated temperature/pressure for a set time period (e.g. $121^{\circ} \mathrm{C}$ for 30 minutes, [23]). Steam is added into the system in order to maintain a prescribed temperature for a given period of time. The steam jacket reduces condensation in the vessel and thus reduces the loss of heat.

In practice, steam is supplied into the system via a boiler. Usually, boilers are heated by means of conventional fuels (such as gas, diesel, coal, or biomass) or they use electricity [24]. The selection of a proper boiler for the system is crucial in terms of having a sufficient amount and quality of steam to match the requirements of a system.

For verification, sufficient steam penetration and exposure time have occurred, biological (spores) or chemical indicators (colour-changing) are placed periodically in waste loads [24].

\subsection{Hydroclaves}

The hydroclave is basically a double-jacketed vessel with fragmenting paddles inside. After the door is closed, high-temperature steam is introduced to the outside jacket to heat the waste via the hot inner surface.

Although the basic principal on which autoclave and hydroclave is based is the same, there is a crucial difference between them in terms of steam recycling. In order for the standard autoclave to function, steam is injected into the sterilising vessel. This steam is then lost when the cycle ends. On the other side, in hydroclave, the steam is injected into the jacket, not into the vessel where the waste is sterilised and therefore the steam is never in contact with waste. This enables the hydroclave to reclaim some amount of steam back to the boiler [25]. However, one of the disadvantages of the hydroclave over the autoclave is that it takes more steam to heat up initially as it has to transfer the heat from the outer jacket into the vessel chamber through conduction. This initial high-energy requirement then diminishes for the continuing cycles.

The healthcare waste, which is treated by alternative treatment plants (autoclave, hydroclave or microwave) requires to be landfilled afterwards. Currently, there is no evidence in the literature reporting the formation of hazardous emissions due to treatment of waste by alternative treatments. However, the electricity, and the fuel oil required to run these plants indirectly cause emissions to be released.

\subsection{Microwaves}

Microwaves are electromagnetic waves with frequencies falling below the range for infrared waves and above the ultra-high frequency [4]. Its working principle is based on converting electrical energy into microwave energy. This microwave energy is used to produce steam from the moisture present in the HCW stream. Some systems apply low-frequency radio waves to inactivate microorganisms contained within the waste.

One of the disadvantages of microwave systems is their cost which might not be economically competitive compared to other technologies, especially in developing countries [26].

\section{EPIDEMIOLOGIC STUDIES OF WASTE TREATMENT METHODS}

Much of the current understanding of the health impacts of waste disposal is based on the application of epidemiological methodology as stated by Hester and Harrison [27]. In this 
part of the study, the available epidemiological literature on the health effects among the workers in landfilling sites and incinerators was reviewed systematically to provide data and information regarding excess risk estimates for the worker's health.

The studies evaluated in this research were selected accordingly to the criteria proposed by Hester and Harrison [27]: (1) They have to be conducted in authorised incinerations or landfills; meaning that the ones considering open burning or unregulated disposal sites were disregarded; (2) They must provide some degree of consistency with other different epidemiological studies in terms of the types and significance of the outcomes; (3) They must have a theoretical basis in linking adverse health effects and exposure pathway and (4) They must have a basis for the effects, as indicated by actual measurements or examinations.

Giusti [28] categorised these studies into three groups:

(1) Prospective Cohort Studies: Two cohorts of people (exposed and non-exposed) who differ with respect to certain factors under study were followed over a period to determine how these factors affected rates of a certain outcome. This kind of study generally involves the collection and analysis of blood or tissue samples. For example: Unuvar et al. [29] conducted a survey to assess whether pregnant women were at risk of mercury intoxication due to fish consumption by taking blood samples from mothers and their new born babies. Mudge et al. [30] described the prevalence of inadequate energy and protein intake in older inpatients by screening consecutive patients admitted between November 2007 and March 2008 to the Royal Brisbane and Women's Hospital in Australia. Likewise Hoek et al. [31] examined the association between mortality and indicators of traffic-related air pollution in the Netherlands by investigating a random sample of 5000 people from 1986 to 1994.

On the other side, having too many repeated measurements and the selection of the measurement time points of cohort studies cause these studies to have an ad-hoc basis according to Tekle et al. [32] who pointed out the necessity of optimal design methods with a controlled budget for these studies.

(2) Retrospective Case-Control Studies: A case group of people who have already developed a specific disease, and a control group of healthy people are selected. Information on past exposure is collected retrospectively (generally via interviews with the participants).

These studies are relatively inexpensive compared to prospective cohort studies as (A) they involve smaller groups of people, (B) they do not generally require structured experiments, but are more prone to bias [28]. For instance: The study by Burke and Sawchuk [33] was based on 244 women who died from tuberculosis between 1874 and 1884 . Some $12 \%$ of them had given birth within the year preceding their death. The study used the records in the local government death registries; and indicated that recent childbirth did not increase the risk of tuberculosis mortality among these women.

(3) Cross-Sectional Studies: They take account a specific group of the exposed population over a short period of time. They are 'cross sectional' because data is collected at one point in time. They can only be useful to generate hypotheses that can be tested later by more comprehensive studies; otherwise they might not be effective at distinguishing whether a particular disease developed before or after the group was exposed to a potential hazard as they do not look at time trends. There are a number of examples of cross-sectional studies in the literature as they are relatively cheap to carry out [34-37]

For the definition of the strength of the association between exposure to a potentially toxic substance and specific health effects in epidemiological studies, the ratio of the incidence of a disease in the exposed population to the incidence of the same disease in the non-exposed population is calculated; this is called "Relative Risk" (RR) or "Odd Risk" (OR). For instance, 
if the RR is 6, the risk is six times higher (or an increase of 500\%) in the exposed population than that in the non-exposed population.

The number of the studies satisfying the criteria set by Hester and Harrison [27] is very limited. Regarding mortality and morbidity among landfill workers, there is only one study: Gelberg [38] carried out a cross-sectional study to examine acute health effects among employees working for the New York City Department of Sanitation. Landfill workers reported a significantly higher prevalence of work-related respiratory $(R R=2.14)$, dermatologic $(\mathrm{RR}=2.07)$, neurologic $(\mathrm{RR}=1.89)$, gastrointestinal $(\mathrm{R}=1.26)$ and hearing problems $(\mathrm{RR}=1.73)$, itching eyes $(\mathrm{RR}=1.54)$ and sorethroat $(\mathrm{R}=2.26)$ than the controls.

Regarding the adverse health effects on incineration workers, Gustavsson [39] investigated mortality among 176 incinerator workers who were employed at least 1 year or more between 1920 and 1985 at a MSW incinerator in Sweden. The results revealed an excess mortality from cancer (oesophageal cancer $\mathrm{RR}=2.84$; stomach cancer $\mathrm{RR}=1.27$, rectal cancer $\mathrm{RR}=$ 2.52 , lung cancer $R R=3.55$, bladder cancer 1.98 , malignant cerebral tumors $R R=2.77$, hematopoietic cancer $R R=1.35)$ and nervous disease $(R R=1.33)$, circulatory disease (ischemic heart disease $R R=1.38$ ), respiratory disease (asthma, bronchitis, emphysema RR $=1.62$ ) and digestive disease (liver cirrhosis $R R=4.54$ ). The excess was found to be high in workers with more than 40 years exposure.

Counter to the above study by Gustavsson [39], a retrospective study on 532 workers employed at two municipal waste incinerators in Rome did not reveal any excess of lung cancer [40]. Mortality from lung cancer was reduced in comparison with the general population and overall cancer mortality did not differ much from that of the general population. However, it was noted a 2.79 fold increased risk of mortality from gastric cancer among workers who had more than 10 years latency since first employment.

A similar study was conducted by Hours et al. [41]; they carried out a cross-sectional morbidity study for 102 workers employed at three French incinerators during 1996, matched for age with 94 male workers from other industrial activities. The exposed workers were categorised into three exposure groups based on their workplace: crane and equipment operators, furnace workers, and maintenance and effluent-treatment workers. The maintenance and effluent group encountered elevated relative risks for skin symptoms $(R R=4.85)$. An excess of daily cough was reported for the maintenance and effluent group $(\mathrm{RR}=2.55)$ and for the furnace group $(\mathrm{RR}=6.58)$.

Many epidemiologic studies dealing with waste management report limitations regarding a lack of good exposure data and the use of surrogate indirect measures which might lead to exposure misclassification [42-45] of the reasons for that is the unsuitableness of conducting an epidemiologic study based on experiments (not on observations) for ethical reasons.

\section{CONCLUSION}

Although there are a number of studies in the literature which provide information on emissions to air from waste treatment facilities, studies surveying the emissions to land or water are very limited in number. This does not mean that health effects due to exposure via water or soil are less significant; however, there are controls on food and water quality, which make any exposures through these pathways easier to avoid. Therefore, inhalation of emissions is the pathway, which is mostly assumed by epidemiological studies.

The greatest challenge emphasised in the current literature so far is the "confounding factors" which might not adequately be controlled in many studies such as ethnicity, gender, socio-economic or deprivation status, age, smoking/alcohol habits, medicinal drug use, occupational history, hazards from other sources, population mobility, long latency period of 
some diseases, the pre-existing health of the people being studied, the wealth or poverty of the people, the availability of health or social care services and other present or historical sources of pollution.

It is known that adverse health impacts would be difficult to prove or supply with decent figures. The main conclusion of the review of the epidemiology literature is that the evidence of adverse health outcomes is controversial as they are insufficient/inadequate and hence inconclusive in providing fully convincing, rigorous epidemiological evidence for an association between waste treatment facilities and adverse health outcomes. It is a fact that future research into the health risks of waste management needs to overcome these current limitations.

It is, therefore, suggested that further collaborative epidemiological studies using a more rigorous approach along with an appropriate methodology which takes account of possible confounding factors are required. It is anticipated that this will benefit in improving a way of shaping public perspective through waste treatment facilities that underlies social values in waste management decision making.

\section{ACKNOWLEDGEMENT}

The author extends her thanks to Tubitak (The Scientific and Technological Research Council of Turkey) for a financial support (project code: 114Y048).

\section{REFERENCES}

[1] Ciplak, N., A system dynamics approach for the determination of adverse health impacts of healthcare waste incinerators and landfill sites on employees. Environmental Management and Sustainable Development, 2(2), pp. 7-28, 2013.

http://dx.doi.org/10.5296/emsd.v2i2.3688

[2] Ciplak, N. \& Barton, J.R., A system dynamics approach for healthcare waste management: a case study in istanbul metropolitan city, Turkey. International Solid Waste Association; Waste Management \& Research, 30(6), pp. 576-586, 2012. http://dx.doi.org/10.1177/0734242X12443405

[3] European Union., Council Directive on Landfill 1999/31/EC. Official Journal of the European Union, Office for Official Publications of the European Communities: Luxembourg, 1999.

[4] Hossain, M.S., Santhanam, A., Nik Norulaini, N.A. \& Omar, A.K.M., Clinical solid waste management practices and its impact on human health and environment - A review. Waste Management, 31(4), 754-766, 2011. http://dx.doi.org/10.1016/j.wasman.2010.11.008

[5] Nemathaga, F., Maringa, S. \& Chimuka, L., Hospital solid waste management practices in Limpopo Province, South Africa: A case study of two hospitals. Waste Management, 28(7), 1236-1245, 2008. http://dx.doi.org/10.1016/j.wasman.2007.03.033

[6] Yong, Z., Gang, X., Guanxing, W., Tao, Z. \& Dawei, J., Medical waste management in China: A case study of Nanjing. Waste Management, 29(4), 1376-1382, 2009. http://dx.doi.org/10.1016/j.wasman.2008.10.023

[7] Hassan, M.M., Ahmed, S.A., Rahman, K.A. \& Biswas, T.K. Pattern of medical waste management: existing scenario in Dhaka City, Bangladesh. BMC Public Health, 8, p. 36, 2008.

http://dx.doi.org/10.1186/1471-2458-8-36 
[8] Da Silva, C.E., Hoppe, A.E., Ravanello, M.M. \& Mello, N., Medical wastes management in the south of Brazil. Waste Management, 25(6), pp. 600-605, 2005. http://dx.doi.org/10.1016/j.wasman.2004.03.002

[9] Bagge, L., Personal Communication. Ms Bagge works for Danish Environment Protection Agency, Copenhagen, Denmark, 2009.

[10] Hempen, S. Personal Communication. Ms Hempen works for Germany Federal Ministry for the Environment, Nature Conservation and Nuclear Safety, Bonn, Germany, 2011.

[11] Karagiannidis, A., Papageorgiou, A., Perkoulidis, G., Sanida, G. \& Samaras, P., A multicriteria assessment of scenarios on thermal processing of infectious hospital wastes: A case study for Central Macedonia. Waste Management, 30(2), pp. 251-262, 2010. http://dx.doi.org/10.1016/j.wasman.2009.08.015

[12] Patil, A.D. \& Shekdar, A.V., Health-care waste management in India. Journal of Environmental Management, 63(2), pp. 211-220, 2001. http://dx.doi.org/10.1006/jema.2001.0453

[13] Askarian, M., Vakili, M. \& Kabir, G., Results of a hospital waste survey in private hospitals in Fars province, Iran. Waste Management, 24(4), pp. 347-352, 2004. http://dx.doi.org/10.1016/j.wasman.2003.09.008

[14] Sawalem, M., Selic, E. \& Herbell, J.D. Hospital waste management in Libya: A case study. Waste Management, 29(4), pp. 1370-1375, 2009. http://dx.doi.org/10.1016/j.wasman.2008.08.028

[15] Coker, A., Sangodoyin, A., Sridhar, M., Booth, C., Olomolaiye, P. \& Hammond, F., Medical waste management in Ibadan, Nigeria: Obstacles and prospects. Waste Management, 29(2), pp. 804-811, 2009. http://dx.doi.org/10.1016/j.wasman.2008.06.040

[16] Al-Khatib, I.A. \& Sato, C., Solid health care waste management status at health care centers in the West Bank - Palestinian Territory. Waste Management, 29(8), pp. 2398-2403, 2009. http://dx.doi.org/10.1016/j.wasman.2009.03.014

[17] Christiansson, J., Personal Communication. Mr Christiansson works for Sweden Environmental Protection Agency Environmental Legal Unit for Products and Waste, Stockholm, Sweden, 2011.

[18] Ciplak, N., Assessing future scenarios for healthcare waste management using a multicriteria decision analysis tool: A case study in the Turkish West Black-Sea Region. The Journal of Air and Waste Management Association, 65(8), pp. 919-929, 2015. http://dx.doi.org/10.1080/10962247.2015.1038398

[19] Tudor, T.L., Townend, W.K., Cheeseman, C. R. \& Edgar, J.E., An overview of arisings and large-scale treatment technologies for healthcare waste in the United Kingdom. Waste Management \& Research, 27(4), pp. 374-383, 2009. http://dx.doi.org/10.1177/0734242X09336244

[20] Yang, C., Peijun, L., Lupi, C., Yangzhao, S., Diandou, X., Qian, F. \& Shasha, F., Sustainable management measures for healthcare waste in China. Waste Management, 29(6), 1996-2004, 2009.

http://dx.doi.org/10.1016/j.wasman.2008.11.031

[21] UK DoH Department of Health., Safe Management of Healthcare Waste Version 1.0, London, 2011.

[22] USEPA United States Environmental Protection Agency., Technical Assistance Manual: State Regulatory Oversight of Medical Waste Treatment Technologies, available at http://www.epa.gov/wastes (accessed January 2009), 1994. 
[23] Stidolph, I. Personal Communication. Mr Stidolph is a Plant Manager of SRCL Ltd, Newcastle, UK.

[24] Emmanuel, J., Hrdinka, C. \& Gluszynski, P., Non-Incineration Medical Waste Treatment Technologies in Europe. Health Care Without Harm Europe. Prague, available at http://www.env-health.org (accessed December 2008), 2004.

[25] Wallis, T., Personal Communication. Mr Wallis is a project manager for Hydroclave Systems Corp. Ltd, Kingston, Ontario, Canada, 2010.

[26] Alagoz, B.A.Z. \& Kocasoy, G., Treatment and disposal alternatives for health-care waste in developing countries - a case study in Istanbul, Turkey. Waste Management \& Research, 25(1), pp. 83-89, 2007. http://dx.doi.org/10.1177/0734242X07069497

[27] Hester, R.E. \& Harrison, R.M., Environmental and Health Impact of Solid Waste Management Activities, Royal Society of Chemistry, available at http://www.knovel.com/ web/portal (accessed July 2009), 2002.

[28] Giusti, L., A review of waste management practices and their impact on human health. Waste Management, 29, pp. 2227-2239, 2009.

http://dx.doi.org/10.1016/j.wasman.2009.03.028

[29] Unuvar, E., Ahmadov, H., Kızıler, A.R., Aydemir, B., Toprak, S., Ulker, V. \& Ark, C., Mercury levels in cord blood and meconium of healthy newborns and venous blood of their mothers: Clinical, prospective cohort study. Science of The Total Environment, 374(1), pp. 60-70, 2007. http://dx.doi.org/10.1016/j.scitotenv.2006.11.043

[30] Mudge, A.M., Ross, L.J., Young, A.M., Isenring, E.A. \& Banks, M.D., Helping understand nutritional gaps in the elderly (HUNGER): A prospective study of patient factors associated with inadequate nutritional intake in older medical inpatients. Clinical Nutrition, 30(3), pp. 320-325, 2011.

http://dx.doi.org/10.1016/j.clnu.2010.12.007

[31] Hoek, G., Brunekreef, B., Goldbohm, S., Fischer, P. \& van den Brandt, P.A., Association between mortality and indicators of traffic-related air pollution in the Netherlands: a cohort study. The Lancet, 360(9341), pp. 1203-1209, 2002.

http://dx.doi.org/10.1016/S0140-6736(02)11280-3

[32] Tekle, F.B., Tan, F.E.S. \& Berger, M.P.F., Too many cohorts and repeated measurements are a waste of resources. Journal of Clinical Epidemiology, 64(12), pp. 1383-1390, 2011.

http://dx.doi.org/10.1016/j.jclinepi.2010.11.023

[33] Burke, S.D.A. \& Sawchuk, L.A., Tuberculosis mortality and recent childbirth: a retrospective case-control study of Gibraltarian women, 1874-1884. Social Science \&amp; Medicine, 56(3), pp. 477-490, 2003.

http://dx.doi.org/10.1016/S0277-9536(02)00048-5

[34] Mino,Y.,Shigemi,J.,Otsu,T.,Ohta,A.,Tsuda,T.,Yasuda,N.,Babazono,A.\&Yamamoto,E., Smoking and mental health: cross-sectional and cohort studies in an occupational setting in Japan. Preventive Medicine, 32(4), pp. 371-375, 2001.

http://dx.doi.org/10.1006/pmed.2000.0803

[35] Peabody,J.W.,Nordyke,R.J.,Tozija,F.,Luck,J.,Muñoz,J.A.,Sunderland,A., DeSalvo,K., Ponce, N. \& McCulloch, C., Quality of care and its impact on population health: A cross-sectional study from Macedonia. Social Science \& Medicine, 62(9), pp. 22162224, 2006.

http://dx.doi.org/10.1016/j.socscimed.2005.10.030 
[36] Scheeres, K., Wensing, M., Severens, H., Adang, E. \& Bleijenberg, G., Determinants of health care use in chronic fatigue syndrome patients: A cross-sectional study. Journal of Psychosomatic Research, 65(1), pp. 39-46, 2008.

http://dx.doi.org/10.1016/j.jpsychores.2008.03.015

[37] Geldart, S., Smith, C.A., Shannon, H.S. \& Lohfeld, L., Organizational practices and workplace health and safety: A cross-sectional study in manufacturing companies. Safety Science, 48(5), pp. 562-569, 2010. http://dx.doi.org/10.1016/j.ssci.2010.01.004

[38] Gelberg, K.H., Health study of New York City Department of Sanitation landfill employees. Journal of Occupational and Environmental Medicine, 39(11), pp. 1103-1110, 1997.

http://dx.doi.org/10.1097/00043764-199711000-00011

[39] Gustavsson, P., Mortality among Workers at a Municipal Waste Incinerator. American Journal of Industrial Medicine, 15(3), pp. 245-253, 1989.

http://dx.doi.org/10.1002/ajim.4700150302

[40] Rapiti, E., Sperati, A., Fano, V., DellOrco, V. \& Forastiere, F., Mortality among workers at municipal waste incinerators in Rome: A retrospective cohort study. American Journal of Industrial Medicine, 31(5), pp. 659-661, 1997.

http://dx.doi.org/10.1002/(SICI)1097-0274(199705)31:5<659::AIDAJIM23>3.0.CO;2-X

[41] Hours, M., Anzivino-Viricel, L., Maitre, A., Perdrix, A., Perrodin, Y., Charbotel, B. \& Bergeret, A., Morbidity among municipal waste incinerator workers: a cross-sectional study. International Archives of Occupational and Environmental Health, 76(6), pp. 467-472, 2003.

http://dx.doi.org/10.1007/s00420-003-0430-0

[42] Rushton, L., Health hazards and waste management. British Medical Bulletin, 68(1), pp. 183-197, 2003. http://dx.doi.org/10.1093/bmb/ldg034

[43] Defra Department for Environment, Food and Rural Affairs. Review of Environmental and Health Effects of Waste Management: Municipal Solid Waste and Similar Wastes Extended Summary. London, Defra commissioned Enviros Consulting Ltd and Birmingham University, available at http://archive.defra.gov.uk/environment/waste/statistics/documents/health-summary (accessed December 2009), 2004a.

[44] Defra Department for Environment, Food and Rural Affairs. Review of Environmental and Health Effects of Waste Management: Municipal Solid Waste and Similar Wastes. Written by Enviros Consulting Ltd and University of Birmingham with Risk and Policy Analysts Ltd, Open University and Maggie Thurgood. London, available at http://archive. defra.gov.uk (accessed December 2009), 2004b.

[45] Porta, D., Milani, S., Lazzarino, A.I., Perucci, C.A. \& Forastiere, F., Systematic review of epidemiological studies on health effects associated with management of solid waste. Environmental Health, 8, p. 60, 2009.

http://dx.doi.org/10.1186/1476-069X-8-60 